\title{
Revised structure and stereochemical assignments of amphidinolide $\mathbf{N}$
}

\author{
Yohei Takahashi ${ }^{1}$, Takaaki Kubota ${ }^{1}$, Misako Imachi $^{2}$, Markus R Wälchli ${ }^{2}$ and Jun’ichi Kobayashi ${ }^{1}$
}

The Journal of Antibiotics (2013) 66, 277-279; doi:10.1038/ja.2012.117; published online 9 January 2013

Keywords: amphidinolide N; Amphidinium sp.; cytotoxic macrolide; dinoflagellate; stereochemistry

Amphidinolides are a series of cytotoxic macrolides isolated from laboratory-cultured marine dinoflagellates Amphidinium sp. ${ }^{1}$ Amphidinolide N (1), ${ }^{2}$ isolated from Amphidinium sp. (Y-5 strain), is a 26-membered macrolide having an allyl epoxide and a tetrahydropyran with 13 chiral centers. Among all amphidinolides isolated so far, amphidinolide $\mathrm{N}(\mathbf{1})$ is the most potent cytotoxic macrolide with $\mathrm{IC}_{50}$ values against murine lymphoma L1210 and human epidermoid carcinoma KB cells in vitro being 0.00005 and $0.00006 \mu \mathrm{g} \mathrm{ml}^{-1}$, respectively. Owing to the complex structure and the extraordinarily potent cytotoxicity, amphidinolide N (1) has been a challenging target for total synthesis. ${ }^{3-6}$ In our previous studies, ${ }^{2}$ gross structure $\mathbf{1 b}$ was proposed based on 2D NMR and mass spectral data, and the configuration of epoxide and the relative stereochemistry of the C-14-C-19 portions were assigned from $J$-values and NOESY data. However, the stereochemistry of the remaining part has not yet been elucidated. Here we describe a revision of the gross structure from $\mathbf{1 b}$ to 1a (Figure 1) and full assignment of the relative stereochemistry of amphidinolide $\mathrm{N}$ (Figure 5).

The molecular formula of amphidinolide $\mathrm{N}$ was established as $\mathrm{C}_{33} \mathrm{H}_{52} \mathrm{O}_{11}$ from ESIMS $\left(\mathrm{m} / z 647(\mathrm{M}+\mathrm{Na})^{+}\right.$(pos.), $\mathrm{m} / z 623(\mathrm{M}-$ $\mathrm{H})^{-}$(neg.)) (in our previous studies, ${ }^{2}$ pseudo molecular ion peaks of amphidinolide $\mathrm{N}, \quad m / z \quad 730(\mathrm{M}+\mathrm{DEA}+\mathrm{H})^{+}$and $m / z \quad 748$
$\left(\mathrm{M}+\mathrm{DEA}+\mathrm{H}_{3} \mathrm{O}\right)^{+}$, were misinterpreted as $\mathrm{m} / z 730(\mathrm{M}+\mathrm{DEA}+$ $\left.\mathrm{H}-\mathrm{H}_{2} \mathrm{O}\right)^{+}$and $m / z 748(\mathrm{M}+\mathrm{DEA}+\mathrm{H})^{+}$, respectively). Deuteriuminduced shifts in ${ }^{13} \mathrm{C}$ NMR resonances for amphidinolide $\mathrm{N}$ were measure by using $\mathrm{C}_{6} \mathrm{D}_{6} / \mathrm{CD}_{3} \mathrm{OH}(3: 1)$ and $\mathrm{C}_{6} \mathrm{D}_{6} / \mathrm{CD}_{3} \mathrm{OD}(3: 1)$ as solvents. Of 11 signals observed for oxygenated $\mathrm{sp}^{3}$ carbons, six oxymethines did not show deuterium-induced upfield shifts (Table 1). Of the unchanged oxymethines, two high-field methine carbons at $\delta$ $54.92(\mathrm{C}-5)$ and $62.98(\mathrm{C}-4)$ in $\mathrm{C}_{6} \mathrm{D}_{6} / \mathrm{CD}_{3} \mathrm{OH}(3: 1)$ were attributed to those of an epoxide ring. Two carbons at $\delta 98.08$ (which did show the upfield shift) and 66.73 were assigned as a hemiacetal carbon at C-15 and an oxymethine carbon at C-19, respectively, whereas an oximethine carbon $(\delta$ 75.66) was elucidated to be that forming a lactone linkage between C-1 and C-25. The remaining two unchanged oxygenated carbons at $\delta 75.61$ and 80.22 were assigned as C-21 and C-24, respectively, suggesting that C-21 and C-24 were not connected to hydroxy groups. The cross-peak of $\mathrm{H}-24$ to $\mathrm{C}-21$ observed in the HMBC spectrum of 1a indicated that C-21 and C-24 were connected to each other through an ether linkage. Thus, the gross structure of amphidinolide $\mathrm{N}$ was revised from $\mathbf{1 b}$ to $\mathbf{1 a}$ (Figure 1).

In our previous studies, ${ }^{2}$ the configuration of the 4,5 -epoxide was deduced to be trans from the coupling constant $\left({ }^{3} J_{\mathrm{H}-4 / \mathrm{H}-5}=1.9 \mathrm{~Hz}\right)$, and the relative stereochemistry of the $\mathrm{C}-14-\mathrm{C}-19$ portions was 1a revised gross structure of amphidinolide $\mathrm{N}$

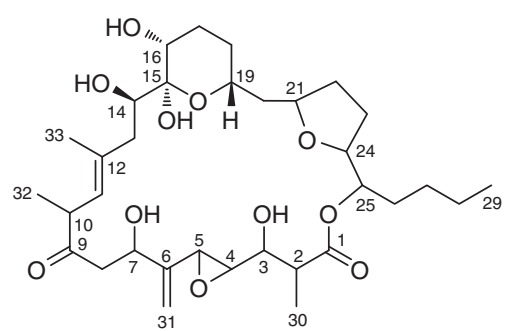

1b proposed gross structure of amphidinolide $\mathrm{N}$

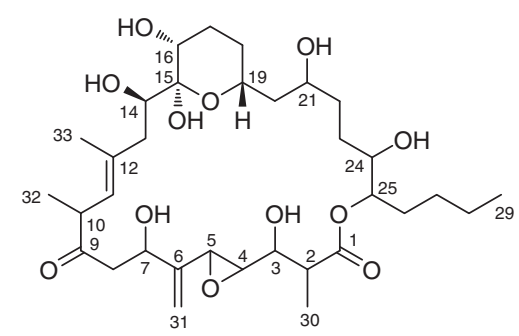

Figure 1 Revised (1a) and proposed (1b) gross structures of amphidinolide $\mathrm{N}$.

${ }^{1}$ Graduate School of Pharmaceutical Sciences, Hokkaido University, Sapporo, Japan and ²Bruker Biospin K.K. 3-9, Moriya-cho, Kanagawa-ku, Yokohama-shi, Kanagawa, Japan Correspondence: Professor J Kobayashi, Graduate School of Pharmaceutical Sciences, Hokkaido University, Sapporo, Hokkaido 060-0812, Japan.

E-mail: jkobay@pharm.hokudai.ac.jp

Received 3 September 2012; revised 29 November 2012; accepted 4 December 2012; published online 9 January 2013 
Table $1{ }^{13} \mathrm{C}$ NMR data of amphidinolide N (1)

\begin{tabular}{|c|c|c|c|}
\hline Position & $\delta_{C}{ }^{a}$ & $\delta_{C}{ }^{\mathrm{b}}$ & $\Delta \delta_{C}{ }^{c}$ \\
\hline 1 & 174.33 & 174.34 & -0.01 \\
\hline 2 & 45.96 & 45.90 & 0.0 \\
\hline 3 & 73.60 & 73.50 & 0.10 \\
\hline 4 & 62.98 & 62.94 & 0.0 \\
\hline 5 & 54.92 & 54.92 & 0.00 \\
\hline 6 & 147.49 & 147.46 & 0.0 \\
\hline 7 & 69.89 & 69.77 & 0.1 \\
\hline 8 & 46.10 & 46.06 & 0.0 \\
\hline 9 & 210.70 & 210.75 & -0.05 \\
\hline 10 & 47.33 & 47.33 & 0.0 \\
\hline 11 & 127.18 & 127.13 & $0 . C$ \\
\hline 12 & 136.75 & 136.75 & 0.0 \\
\hline 13 & 40.45 & 40.39 & 0. \\
\hline 14 & 71.38 & 71.27 & 0.1 \\
\hline 15 & 98.08 & 97.98 & 0. \\
\hline 16 & 65.74 & 65.59 & 0. \\
\hline 17 & 27.37 & 27.34 & 0. \\
\hline 18 & 25.72 & 25.72 & 0. \\
\hline 19 & 66.73 & 66.74 & -0.01 \\
\hline 20 & 42.02 & 42.01 & 0.0 \\
\hline 21 & 75.61 & 75.62 & -0.0 \\
\hline 22 & 32.99 & 32.98 & 0.0 \\
\hline 23 & 28.01 & 28.01 & 0. \\
\hline 24 & 80.22 & 80.22 & $0 . C$ \\
\hline 25 & 75.66 & 75.66 & 0. \\
\hline 26 & 31.38 & 31.38 & 0. \\
\hline 27 & 27.91 & 27.91 & $0 . C$ \\
\hline 28 & 22.74 & 22.74 & $0 . C$ \\
\hline 29 & 14.16 & 14.17 & -0.0 \\
\hline 30 & 13.94 & 13.94 & 0. \\
\hline 31 & 111.73 & 111.75 & -0.0 \\
\hline 32 & 15.59 & 15.58 & 0. \\
\hline 33 & 15.05 & 15.05 & 0. \\
\hline
\end{tabular}

${ }^{\mathrm{a}} \delta_{\mathrm{C}}$ in $\mathrm{C}_{6} \mathrm{D}_{6} / \mathrm{CD}_{3} \mathrm{OH}, 3: 1$.

${ }^{b_{0}} \delta_{C}$ in $\mathrm{C}_{6} \mathrm{D}_{6} / \mathrm{CD}_{3} \mathrm{OD}, 3: 1$.

${ }^{\mathrm{c}} \Delta \delta_{\mathrm{C}}=\delta_{\mathrm{C}}\left(\right.$ in $\left.\mathrm{C}_{6} \mathrm{D}_{6} / \mathrm{CD}_{3} \mathrm{OH}, 3: 1\right)-\delta_{\mathrm{C}}\left(\right.$ in $\left.\mathrm{C}_{6} \mathrm{D}_{6} / \mathrm{CD}_{3} \mathrm{OD}, 3: 1\right)$
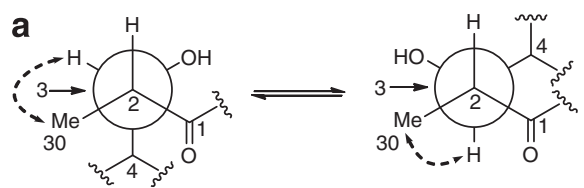

${ }^{3} \mathrm{~J}_{\mathrm{H}-2 / \mathrm{H}-3}=7.2 \mathrm{~Hz}$

${ }^{3} J_{\mathrm{C}-4 / \mathrm{H}-2}=3.3 \mathrm{~Hz}$

${ }^{3} J_{\mathrm{C}-1 / \mathrm{H}-3}=3.4 \mathrm{~Hz}$

${ }^{2} J_{\mathrm{C}-3 / \mathrm{H}-2}=-4.7 \mathrm{~Hz}$
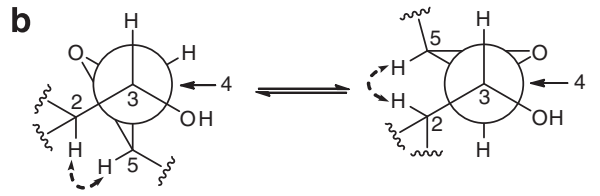

${ }^{3} J_{\mathrm{H}-3 / \mathrm{H}-4}=4.6 \mathrm{~Hz}$

${ }^{3} J_{\mathrm{C}-5 / \mathrm{H}-3}=4.6 \mathrm{~Hz}$

${ }^{3} J_{\mathrm{C}-2 / \mathrm{H}-4}=3.3 \mathrm{~Hz}$

${ }^{2} J_{\mathrm{C}-4 / \mathrm{H}-3}=-3.2 \mathrm{~Hz}$

$\rightarrow-\rightarrow$ NOESY

Figure 2 Rotation models for (a) C-2-C-3 and (b) C-3-C-4 bonds of amphidinolide $\mathrm{N}$.

elucidated from $J$-values and NOESY data. In this study, the relative stereochemistry of the C-2-C-4 segment was analyzed by the J-based configuration analysis method. ${ }^{7}$ The values for ${ }^{3} J_{\mathrm{H}-2 / \mathrm{H}-3}(7.2 \mathrm{~Hz}),{ }^{3} \mathrm{~J}_{\mathrm{C}}$

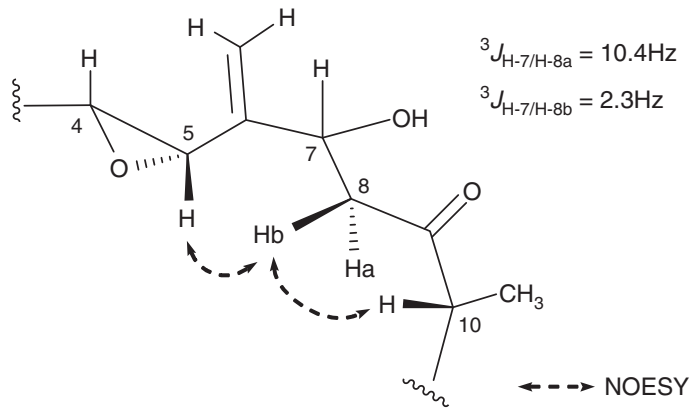

Figure 3 Selected NOESY correlations and relative stereochemistry for amphidinolide N (C-4-C-10 part).

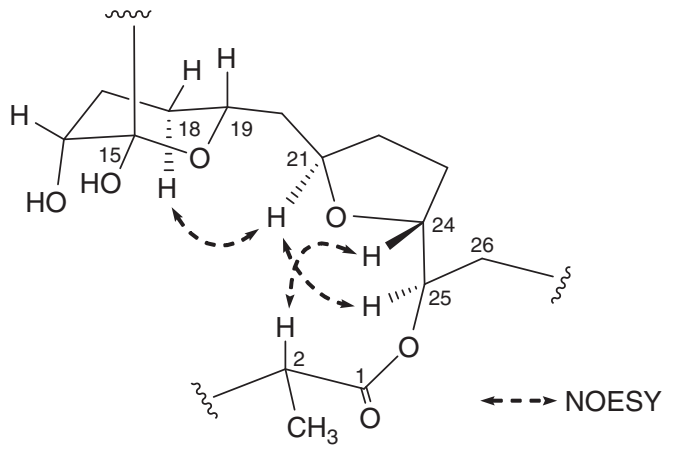

Figure 4 Selected NOESY correlations and relative stereochemistry for amphidinolide N (C-15-C-26 and C-1-C-2 parts).

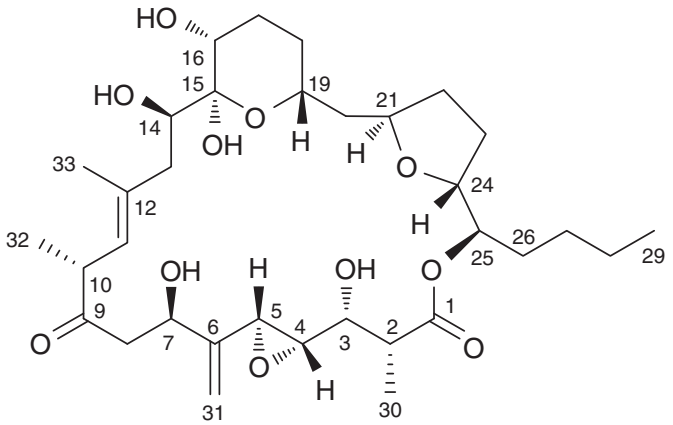

Figure 5 Relative stereochemistry of amphidinolide N (1).

$4 / \mathrm{H}-2(3.3 \mathrm{~Hz}),{ }^{3} \mathrm{~J}_{\mathrm{C}-1 / \mathrm{H}-3}(3.4 \mathrm{~Hz})$ and ${ }^{2} J_{\mathrm{C}-3 / \mathrm{H}-2}(-4.7 \mathrm{~Hz})$, which were obtained from the ${ }^{1} \mathrm{H}$ NMR and J-HMBC ${ }^{8-12}$ spectra, indicated that C-1 was gauche to $\mathrm{C}-4, \mathrm{H}-2$ was gauche to $3-\mathrm{OH}$ and $\mathrm{H}-3$ was gauche to $\mathrm{C}-30$. The gauche relation between the $\mathrm{H}-3$ and $\mathrm{C}-30$ was deduced from the intense NOESY correlation for $\mathrm{H}-3 / \mathrm{H}_{3}-30$ as well, suggesting the threo relation for the C-2-C-3 bond (Figure 2a). The values for ${ }^{3} J_{\mathrm{H}-3 / \mathrm{H}-4}(4.6 \mathrm{~Hz}),{ }^{3} J_{\mathrm{C}-5 / \mathrm{H}-3}(4.6 \mathrm{~Hz}),{ }^{3} \mathrm{~J}_{\mathrm{C}-2 / \mathrm{H}-4}(3.3 \mathrm{~Hz})$ and ${ }^{2} J_{\mathrm{C}-4 / \mathrm{H}-3}$ $(-3.2 \mathrm{~Hz})$, and the intense NOESY correlation for $\mathrm{H}-2 / \mathrm{H}-5$ indicated that C-2 was gauche to C-5, H-3 was gauche to $\mathrm{O}-4$ and $\mathrm{H}-4$ was 
gauche to $3-\mathrm{OH}$, suggesting assignment of the relative configuration of C-3-C-4 as threo (Figure 2b).

The relative stereochemistry of the C-5-C-10 segment was deduced from $J$-values and NOESY data. The values for ${ }^{3} J_{\mathrm{H}-7 / \mathrm{H}-8 \mathrm{a}}(10.4 \mathrm{~Hz})$ and ${ }^{3} J_{\mathrm{H}-7 / \mathrm{H}-8 \mathrm{~b}}(2.3 \mathrm{~Hz})$ indicated an anti relationship for $\mathrm{H}-7$ and $\mathrm{H}-8 \mathrm{a}$, while NOESY correlations of $\mathrm{H}-5 / \mathrm{H}-8 \mathrm{~b}$ and $\mathrm{H}-8 \mathrm{~b} / \mathrm{H}-10$ showed proximity of $\mathrm{H}-5, \mathrm{H}-8 \mathrm{~b}$ and $\mathrm{H}-10$, reading to the relative configurations shown in Figure 3.

Proximity of $\mathrm{H}-18, \mathrm{H}-21$ and $\mathrm{H}-25$ was indicated by NOESY correlations of $\mathrm{H}-18 / \mathrm{H}-21$ and $\mathrm{H}-21 / \mathrm{H}-25$, suggesting that the relative stereochemistry of $\mathrm{H}-21$ and $\mathrm{H}-24$ in the tetrahydrofuran ring was anti. The proximity of $\mathrm{H}-24$ and $\mathrm{H}-2$ was deduced from the NOESY correlation of $\mathrm{H}-24 / \mathrm{H}-2$. The relative configurations from C-15 through C-2 as shown in Figure 4 were suggested by these NOESY correlations. Thus, the relative stereochemistry of amphidinolide $\mathrm{N}$ (1) was elucidated as shown in Figure 5.

\section{ACKNOWLEDGEMENTS}

We thank Ms S Oka and Ms M Kiuchi, Instrumental Analysis Division, Equipment Management Center, Creative Reseach Institution, Hokkaido University, for measurements of ESIMS. This work was partly supported by a research fellowship for young scientists from the Japan Society for the Promotion of Science (to YT), the Akiyama Life Sience Foundation, the Suhara Memorial Foundation and Grant-in-Aid for Scientific Research on Innovative Areas (Biosynthetic Machinery) from the Ministry of Education, Culture, Sports, Science and Technology of Japan.
1 Kobayashi, J. \& Kubota, T. In Comprehensive Natural Products II: Chemistry and Biology Vol. 2 (ed. Mander, L. \& Lui, H.-W.) 263-325 (Elsevier Science, Oxford, 2010).

2 Ishibashi, M., Yamaguchi, N., Sasaki, T. \& Kobayashi, J. Amphidinolide N, a novel 26-membered macrolide with remarkably potent cytotoxicity from the cultured marine dinoflagellate Amphidinium sp. J. Chem. Soc., Chem. Commun. 1455-1456 (1994).

3 Nicolaou, K. C., Brenzovich, W. E. \& Bulger, P. G. Synthesis of iso-epoxy-amphidinolide $\mathrm{N}$ and des-epoxy-caribenolide I structures. Initial forays. Org. Biomol. Chem. 4, 2119-2157 (2006).

4 Nicolaou, K. C., Bulger, P. G., Brenzovich, W. E. \& Francis, T. M. Synthesis of isoepoxy-amphidinolide $\mathrm{N}$ and des-epoxy-caribenolide I structures. Revised strategy and final stages. Org. Biomol. Chem. 4, 2158-2183 (2006).

5 Seck, M., Franck, X., Seon-Meniel, B., Hocquemiller, R. \& Figadére, B. A Baylis-Hillman approach to the synthesis of $C_{1}-C_{11}$ fragment of caribenolide I. Tetrahedron Lett. 47, 4175-4180 (2006).

6 Trost, B. M. \& Rey, J. Diastereoselective formation of tetrahydrofurans via Pd-catalyzed asymmetric allylic alkylation: synthesis of the C13-C29 subunit of amphidinolide $\mathrm{N}$. Org. Lett. 14, 5632-5635 (2012)

7 Matsumori, N., Kaneno, D., Murata, M., Nakamura, H. \& Tachibana, K. Stereochemical determination of acyclic structures based on carbon - proton spin-coupling constants. A method of configuration analysis for natural products. J. Org. Chem. 64, 866-876 (1999).

8 Zhu, G., Live, D. \& Bax, A. Analysis of sugar puckers and glycosidic torsion angles in a DNA G-tetrad structure by heteronuclear three-bond J couplings. J. Am. Chem. Soc. 116, 8370-8371 (1994).

9 Willker, W. \& Leibfritz, D. Determination of heteronuclear long-range $H, X$ coupling constants from gradient-selected HMBC spectra. Magn. Reson. Chem. 33, 632-638 (1995).

10 Sheng, S. \& Halbeek, H. V. Accurate and precise measurement of heteronuclear longrange couplings by a gradient-enhanced two-dimensional multiple-bond correlation experiment. J. Magn. Reson. 130, 296-299 (1998).

11 Furihata, K. \& Seto, H. J-Resolved HMBC, a new NMR technique for measuring heteronuclear long-range coupling constants. Tetrahedron Lett. 40, 6271-6275 (1999).

12 Keyang, D. Direct measurement of heteronuclear long-range coupling constants from phase-sensitive HMBC spectra. Magn. Reson. Chem. 38, 321-323 (2000). 